\title{
RAPIDITY OF ANTIGENIC MODULATION \\ OF BORDETELLA PERTUSSIS IN MODIFIED HORNIBROOK MEDIUM
}

\author{
E. O. IdigbE*, R. Parton and A. C. Wardlaw \\ Department of Microbiology, Glasgow University, Alexander Stone Building, \\ Garscube Estate, Bearsden, Glasgow G61 1QH
}

\begin{abstract}
SUMMARY. Modulation of Bordetella pertussis was induced by growth in Hornibrook medium with a high content of magnesium sulphate (C-medium); four pathophysiological activities in the cells or in the whole culture were measured at intervals. Modulation, shown by the extensive loss of protective antigen, histamine-sensitising factor, leukocytosis-promoting factor, heat-labile toxin and X-mode specific envelope proteins, occurred during the first $10 \mathrm{~h}$ of incubation of $\mathrm{X}$-mode cells in C-medium at $35^{\circ} \mathrm{C}$ and before the onset of the logarithmic phase of growth. The rapidity of these losses was greater than could be explained by a simple growth-dilution effect and did not appear to be due to release of activity into the culture fluid. It seemed, therefore, that there was selective destruction of pathophysiological activities as well as cessation of synthesis. The activities appeared to be lost at different rates. Mouse-protective activity was lost more rapidly than histaminesensitising and leukocytosis-promoting activities; heat-labile toxicity was lost more slowly or less completely. Modulation was shown to be easily reversed.
\end{abstract}

\section{INTRODUCTION}

The composition of the growth medium has a profound influence on the immunological and pathophysiological activities of Bordetella pertussis. Lacey (1960) reported that the haemagglutinin, agglutinogens and mouse virulence associated with cells grown normally were lost during growth on a medium containing a high concentration of $\mathrm{MgSO}_{4}$. This was one example of a reversible phenotypic change affecting the whole population in a culture, which he termed "antigenic modulation". It is distinct from the mutationdependent phase variation of Leslie and Gardner (1931) and is similar to the nicotinic acid-induced modulation of B. pertussis (Pusztai and Joó, 1967). Lacey (1960) introduced the term "X-mode" for cells with haemagglutinin, certain agglutinogens and mouse virulence, and " $\mathrm{C}$-mode" for cells that had

Received 13 Feb. 1981; accepted 25 Mar. 1981.

* Present address: National Institute for Medical Research, Edmond Crescent, PMB 2013, Yaba, Nigeria. 
lost these properties as a result of growth in a medium with a high concentration of $\mathrm{MgSO}_{4}$. Later studies showed that protective antigen (PA), histamine-sensitising factor (HSF), leukocytosis-promoting factor (LPF), heat-labile toxin (HLT), adenylate cyclase activity and 28k and 30k envelope polypeptides of $B$. pertussis were also lost in similar growth conditions (Parton and Wardlaw, 1975; Wardlaw, Parton and Hooker, 1976; Livey, Parton and Wardlaw, 1978; Parton and Durham, 1978). There was some indication from Lacey's work that the haemagglutinin was lost faster than the agglutinogens, but the sequence of loss of the other properties was not examined.

The aim of this investigation was to determine the rate of loss of the activities of X-mode cells after transfer to a medium with a high concentration of $\mathrm{MgSO}_{4}$ and to explore the possibility of using antigenic modulation to obtain cells in which the normal ratio of activities was altered. The reversibility of the various changes was also examined.

\section{MATERIALS AND METHODS}

Organism. B. pertussis strain 18334 , a vaccine strain obtained originally from Connaught Laboratories Ltd, Toronto, was used throughout this investigation.

Cultures. Stock cultures were grown on Bordet-Gengou (BG) medium (Gibco-Biocult Diagnostics, Paisley, Scotland) containing $20 \%$ (v/v) defibrinated horse blood (Gibco-Biocult) for $72 \mathrm{~h}$ at $35^{\circ} \mathrm{C}$ in a moist atmosphere. Bulk liquid cultures were grown in modified Hornibrook medium (X-medium) or in modified Hornibrook medium in which the $\mathrm{NaCl}(0.5 \%$ $\mathrm{w} / \mathrm{v})$ was replaced by $0.5 \%(\mathrm{w} / \mathrm{v}) \mathrm{MgSO}_{4} .7 \mathrm{H}_{2} \mathrm{O}$ (C-medium; Wardlaw et al., 1976); the $\mathrm{X}$ to $\mathrm{C}$ and $\mathrm{C}$ to $\mathrm{X}$ changes were studied. Seed cultures were prepared by inoculating a loopful of growth from BG medium into $1 \mathrm{~L}$ of $\mathrm{X}$-medium or $\mathrm{C}$-medium contained in a 2-L dimpled conical flask. The flasks were incubated at $35^{\circ} \mathrm{C}$ for $48 \mathrm{~h}$ in an orbital incubator at $80 \mathrm{rpm}$. Several 2-L dimpled flasks containing $900 \mathrm{ml}$ of X- or C-medium were each inoculated with $100 \mathrm{ml}$ of the seed culture and incubated as above. Cultures were harvested by centrifugation at $10000 \mathrm{~g}$ for $30 \mathrm{~min}$ at $4{ }^{\circ} \mathrm{C}$. The cell pellets were resuspended in $0.85 \%(\mathrm{w} / \mathrm{v}) \mathrm{NaCl}$ solution and heated at $56^{\circ} \mathrm{C}$ for $30 \mathrm{~min}$, unless otherwise stated, to kill the bacteria and inactivate the heat-labile toxin. Thiomersal was added as preservative to give a final concentration of $0 \cdot 1 \mathrm{mg} / \mathrm{ml}$ and the suspensions were stored at $4^{\circ} \mathrm{C}$. The concentration of bacteria in a suspension was determined, before heating, by comparison with the 5th International Reference of Opacity (World Health Organization International Laboratory for Biological Standards, National Institute for Biological Standards and Controls, Holly Hill, London NW3 6RB).

Estimation of viable cell numbers and optical densities. Serial tenfold dilutions of cultures were made in sterile saline and duplicate $0.2-\mathrm{ml}$ portions of each dilution were spread on BG plates. After incubation at $35^{\circ} \mathrm{C}$ for $72 \mathrm{~h}$, plates with countable colonies were selected. The average number of colonies per dilution was multiplied by the dilution factor to give an estimate of the number of viable cells $/ \mathrm{ml}$ of the original culture. Optical-density measurements on cultures were made at a wavelength of $540 \mathrm{~nm}$ in a Pye-Unicam, model SP500 spectrophotometer with polystyrene cuvettes and a 1-cm light path.

Assay of $P A$ and $H S F$ and evaluation of the results by the probit method were as described by Wardlaw et al. (1976) with suspensions adjusted to the same opacity value.

Assay of $L P F$ was done in groups of five 5-week-old female mice of the HAM/ICR strain after intravenous injection of $0.2 \mathrm{ml}$ of the test material into each mouse. Control mice were given an injection of saline only. Blood was obtained from the animals 4 days later from the orbital plexus and $40 \mu \mathrm{l}$ of blood were immediately transferred with a Coulter pipette to plastic vials containing $20 \mathrm{ml}$ of Isoton II diluent (Coulter Electronics Ltd, Harpenden, Herts) to give a final blood concentration of 1 in 501. Six drops of Zap-Oglobin (Coulter Electronics Ltd) were added to each vial to lyse the red blood cells. The white blood cells were counted with a Coulter 
counter model FN (Coulter Electronics Ltd) at a threshold setting of 20 and attenuation and aperture settings of 1 and 0.707 respectively. Counts were corrected for dilution, coincidence and excessive background and expressed as the mean of the $\log _{10}$ counts per group of mice. Leukocyte counts were expressed as $\log _{10}$ values because their distribution was closer to a log-normal than to a normal distribution.

LPF activities of unknown samples and standards were compared by a four-point parallel-line assay (Finney, 1964) with groups of 10 mice at each dilution and with a dilution interval of twofold. The $\mathrm{C}$-mode preparations were compared with the $\mathrm{X}$-mode preparations with the latter as standards. X-mode samples from various stages of growth were also compared with a standard freeze-dried X-mode vaccine. Results of the four-point assay were analysed by computer and the potency values and $95 \%$ confidence limits of the unknown preparations relative to the standards were obtained.

Assay of HLT. Groups of five three-week-old mice were given intraperitoneal injection with $0.5 \mathrm{ml}$ of graded doses of unheated samples of $B$. pertussis. Deaths were recorded during the next three days and the results evaluated by the probit method.

Slab-gel electrophoresis. SDS-polyacrylamide-gel electrophoresis of X-mode and C-mode samples was done by the methods described by Parton and Wardlaw (1975).

\section{RESULTS}

\section{Rate of growth in $X$ - and C-media}

$B$. pertussis strain 18334 was grown in $\mathrm{X}$ - and $\mathrm{C}$-media to give normal $\mathrm{X}$-mode and variant (C-mode) cultures. At various intervals, optical density and numbers of viable cells were estimated, and suspensions of centrifuged, resuspended, heat-killed cells were assayed for the four pathophysiological activities. The viable counts in a typical experiment showed that the cells in Xand in C-media grew at approximately the same rate, although there was an initial lag period in the $\mathrm{C}$-mode cultures (figure, $\mathrm{A}$ ). The mean generation time during the logarithmic phase for cells in X-and in C-media was approximately 6-7 h. Despite the close similarity of the viable counts of $\mathrm{X}$-mode and $\mathrm{C}$-mode cultures at any given time, the optical densities of the $\mathrm{C}$-mode cultures were consistently higher than those of the X-mode cultures throughout growth (figure, B).

\section{$X$ to $C$ modulation}

Cell suspensions obtained at various intervals during the growth of $B$. pertussis strain 18334 in X-and C-media were assayed for PA, HSF, LPF and HLT.

Mouse-protective activity. The protective activity of 10-h X-mode cells did not differ significantly from that of the 48-h X-mode cells in four independent experiments (table I). However, the values obtained for cells incubated in $\mathrm{C}$-medium were much lower; after growth for $10 \mathrm{~h}$ and $48 \mathrm{~h}$ in C-medium, the cells had only $c .1 \cdot 2 \%$ and $0.5 \%$ respectively of the PA of cells grown in $\mathrm{X}$-medium. The residual activity in C-mode cells was too low to measure accurately and the difference between $1.2 \%$ and $0.5 \%$ is not significant.

In view of this rapid loss of protective activity in C-medium, the extent of loss that would be expected if there had been neither synthesis nor destruction 

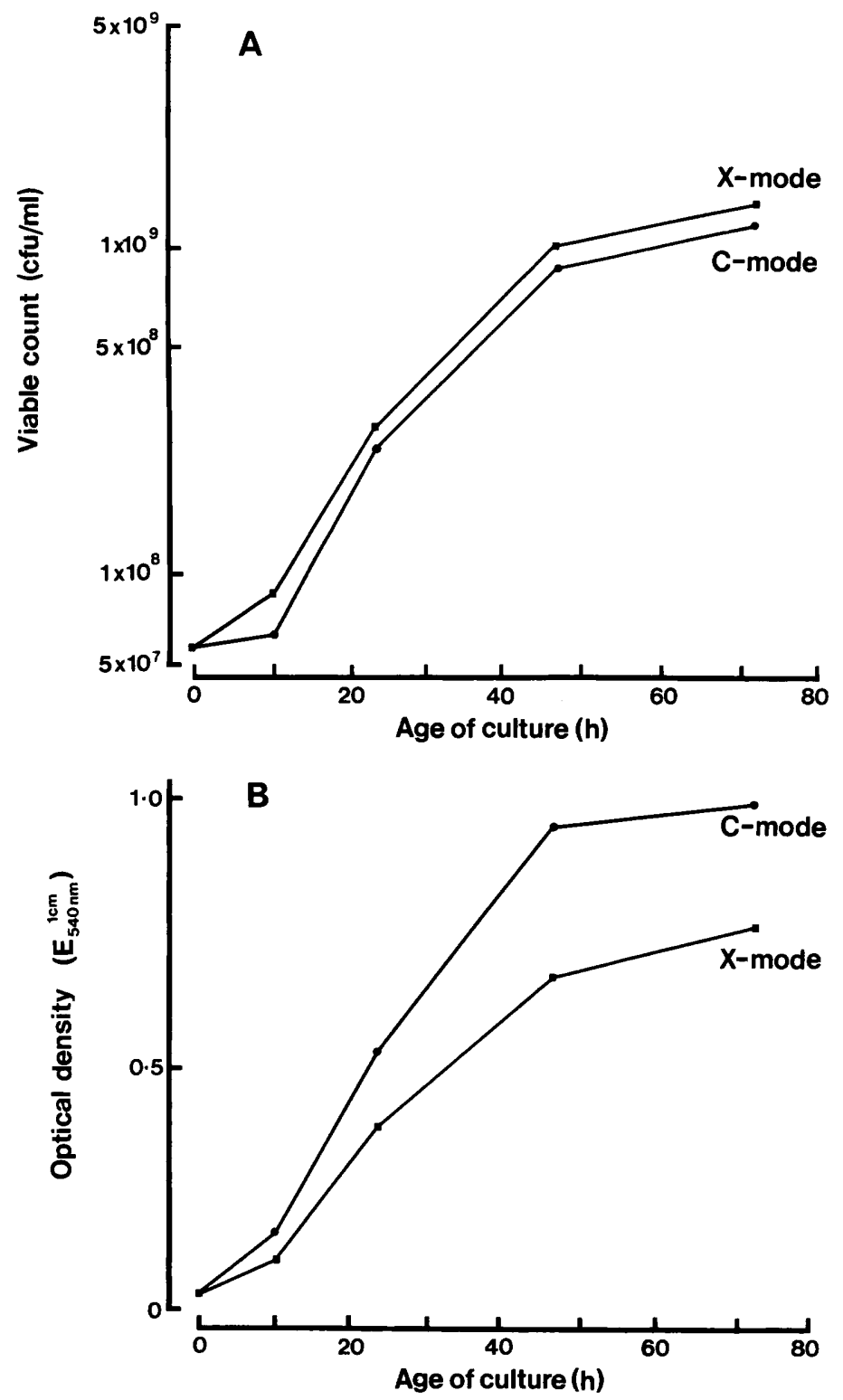

FIGURE--Changes in (A) number of viable cells and (B) optical density during growth of $B$. pertussis strain 18334 in X-medium and C-medium. A 10\% (v/v) inoculum of a 48-h X-mode culture was used. 
TABLE I

Mouse-protective activity of Bordetella pertussis cells harvested from $X$-medium and C-medium seeded with an $X$-mode inoculum

\begin{tabular}{|c|c|c|c|c|c|c|}
\hline \multirow{2}{*}{$\begin{array}{c}\text { Growth medium } \\
\text { and sampling } \\
\text { time }\end{array}$} & \multicolumn{4}{|c|}{$\begin{array}{l}\text { Relative potency (and } 95 \% \text { confidence } \\
\text { limits) of PA in cells in }\end{array}$} & \multirow{2}{*}{$\begin{array}{c}\text { Weighted mean } \\
\text { relative potency } \\
\text { (and } 95 \% \text { confidence } \\
\text { limits) } \\
\end{array}$} & \multirow{2}{*}{$\begin{array}{l}\text { Expectec } \\
\text { relative } \\
\text { potency }\end{array}$} \\
\hline & expt 1 & expt 2 & expt 3 & expt 4 & & \\
\hline $\mathrm{X}$-medium & $\begin{array}{c}52 \\
(9-860)\end{array}$ & $\begin{array}{c}52 \\
(9-240)\end{array}$ & $\begin{array}{c}52 \\
(19-340)\end{array}$ & $\begin{array}{c}82 \\
(16-390)\end{array}$ & $\begin{array}{c}70 \\
(29-170)\end{array}$ & 100 \\
\hline $\begin{array}{c}\mathrm{X} \text {-medium } \\
48 \mathrm{~h}\end{array}$ & $100^{*}$ & 100 & 100 & 100 & 100 & 100 \\
\hline $\begin{array}{c}\mathrm{C} \text {-medium } \\
10 \mathrm{~h}\end{array}$ & $\begin{array}{c}0 \cdot 6 \\
(0-6)\end{array}$ & $\begin{array}{c}0 \cdot 9 \\
(0 \cdot 1-4)\end{array}$ & $\begin{array}{c}1 \cdot 5 \\
(0 \cdot 3-6)\end{array}$ & $\begin{array}{c}1 \cdot 3 \\
(0 \cdot 2-6)\end{array}$ & $\begin{array}{c}1 \cdot 2 \\
(0 \cdot 5-3)\end{array}$ & 77 \\
\hline $\mathrm{C}$-medium & $\begin{array}{c}0.1 \\
(0-0.8)\end{array}$ & $\begin{array}{c}0.5 \\
(0 \cdot 1-2 \cdot 4)\end{array}$ & $\begin{array}{c}0 \cdot 8 \\
(0 \cdot 2-4)\end{array}$ & $\begin{array}{c}0 \cdot 4 \\
(0-2)\end{array}$ & $\begin{array}{c}0 \cdot 5 \\
(0 \cdot 2-1)\end{array}$ & 15 \\
\hline
\end{tabular}

PA $=$ mouse-protective antigen.

* 48-h X-mode cells taken as reference standard and assigned the value 100

$\uparrow$ Based on observed number of cell divisions and assuming no synthesis and no inactivation of PA.

of PA was calculated. If the original PA in the inoculum had simply been diluted amongst progeny cells, the expected relative potencies of the C-mode cells based upon the number of cell divisions that had occurred would have been $77 \%$ and $15 \%$ for 10 -h and 48 -h C-mode cultures respectively (table I). This indicates that the PA was being inactivated.

Histamine-sensitising activity. The weighted mean relative HSF potency values from several independent growth experiments are shown in table II. The HSF activity, per unit of opacity, remained constant during growth of cells in X-medium. However, there was a rapid decrease in activity when the cells

TABLE II

Histamine-sensitising activity of $B$. pertussis cells harvested from $X$-medium and $C$-medium seeded with an $X$-mode inoculum

\begin{tabular}{|c|c|c|c|}
\hline \multirow[t]{2}{*}{$\begin{array}{l}\text { Age of } \\
\text { culture }\end{array}$} & \multicolumn{2}{|c|}{$\begin{array}{l}\text { Weighted mean relative } \\
\text { potency value* (and } \\
95 \% \text { confidence limits } \\
\text { from six independent } \\
\text { experiments) of HSF } \\
\text { in cells from }\end{array}$} & \multirow[t]{2}{*}{$\begin{array}{l}\text { Expected relative } \\
\text { potency of C-mode } \\
\text { cells } \dagger\end{array}$} \\
\hline & $\mathrm{X}$-medium & C-medium & \\
\hline $10 \mathrm{~h}$ & $\begin{array}{c}99 \\
(56-179)\end{array}$ & $\begin{array}{c}11 \cdot 0 \\
(5 \cdot 7-19)\end{array}$ & 82 \\
\hline $24 \mathrm{~h}$ & $\begin{array}{c}106 \\
(64-206)\end{array}$ & $\begin{array}{c}4.7 \\
(1 \cdot 5-8 \cdot 1)\end{array}$ & 16 \\
\hline $48 \mathrm{~h}$ & $100^{*}$ & $\begin{array}{c}1 \cdot 8 \\
(0 \cdot 00-12)\end{array}$ & 8 \\
\hline $72 \mathrm{~h}$ & $\begin{array}{c}107 \\
(58-185)\end{array}$ & $\begin{array}{c}1.8 \\
(0.00-12)\end{array}$ & 6 \\
\hline
\end{tabular}

HSF $=$ histamine-sensitising factor.

* $48 \mathrm{~h}$ X-mode cells taken as reference standard and assigned the value 100 .

$\dagger$ Based on observed number of cell divisions and assuming no synthesis and no inactivation of HSF. 
were grown in $\mathrm{C}$-medium; at $10 \mathrm{~h}$ the activity was only $11 \%$ of that shown by cells grown in X-medium and at $48 \mathrm{~h}$ the cells from $\mathrm{C}$-medium had only $2 \%$ of the HSF of their X-mode counterparts.

To determine whether loss of HSF activity in C-mode cells could be accounted for solely by dilution amongst progeny cells, the correlation between HSF and number of viable cells up to the end of log-phase growth was examined. The expected relative potencies of $\mathrm{C}$-mode cells based upon the number of cell divisions that had occurred are shown in table II. As with PA, the loss of HSF activity in the C-mode cells was much faster than could be explained by a simple growth-dilution effect and suggested that HSF was being inactivated.

HSF activity is liberated into the extracellular fluid during normal growth of B. pertussis (Munoz, 1971). To determine whether the loss of activity in $\mathrm{C}$-mode cells was due to this liberation, samples of C-mode whole cultures, as distinct from the centrifuged and resuspended cells used above, and culture supernates were obtained at various intervals during growth and assayed for HSF. With whole culture and with supernate there was a progressive decline in HSF activity from the time the cultures were seeded. Thus, in the $\mathrm{C}$-mode whole culture, the initial activity due to the X-mode inoculum was not conserved and the loss of activity in the cells could not be explained by release of the HSF into the culture fluid.

Leukocytosis-promoting activity. Cell samples obtained at various intervals during growth in several independent experiments were assayed for LPF and gave consistent results. The LPF potency of cells taken at $10 \mathrm{~h}$ from $\mathrm{C}$-medium was only $20 \%$ of the potency of 10 -h X-mode cells (table III). The four-point assay could not be used for estimation of the LPF potencies of older $\mathrm{C}$-mode samples due to the very low level of activity present. The potencies of the X-mode samples ranged from 96 to $150 \%$ but the range of the $95 \%$

TABLE III

Leukocytosis-promoting activity of $B$. pertussis cells harvested from $X$-medium and $C$-medium seeded with an $X$-mode inoculum

\begin{tabular}{c|cc}
\hline \multirow{2}{*}{ Age of culture } & \multicolumn{2}{c}{$\begin{array}{c}\text { Relative potency (and } \\
95 \% \text { confidence limits) } \\
\text { of LPF in cells from }\end{array}$} \\
\cline { 2 - 3 } & X-medium & C-medium $\dagger$ \\
\hline $10 \mathrm{~h}$ & $100^{*}$ & 20 \\
$24 \mathrm{~h}$ & $\begin{array}{c}150 \\
(65-38)\end{array}$ & $<5$ \\
$48 \mathrm{~h}$ & $\begin{array}{c}150 \\
(71-336)\end{array}$ & $<5$ \\
$72 \mathrm{~h}$ & 96 & $<5$ \\
\hline
\end{tabular}

$\mathrm{LPF}=$ leukocytosis-promoting factor.

* 10-h X-mode cells taken as reference standard and assigned the value 100 .

$\dagger$ See table II column 4 for expected potency values. 
confidence limits shows that there was no significant difference between these values. With cells from C-medium, the expected potency based upon the estimated number of cell divisions after $10 \mathrm{~h}$ was $82 \%$. The actual value of $20 \%$ indicated that the loss of LPF was not due solely to dilution amongst progeny cells and it appears that the original LPF was degraded or denatured when cells from an X-mode inoculum were grown in C-medium.

Heat-labile toxin. In several independent experiments the mouse-lethal toxicity in unheated $48-\mathrm{h} \mathrm{X}$ - and $\mathrm{C}$-mode cell suspensions was measured. The individual estimates of the potency of C-mode cells relative to the X-mode cells ranged from 18.8 to $25 \%$ with a weighted mean of $22 \%$. Thus, even after growth for $48 \mathrm{~h}$, the cells from $\mathrm{C}$-medium retained relatively much more mouse-lethal toxicity than they did PA, HSF or LPF. In X-and in C-mode cells the toxicity was abolished when samples were heated at $56^{\circ} \mathrm{C}$ for $30 \mathrm{~min}$, indicating that the toxicity was due to HLT and not to endotoxin.

Changes in the electrophoretic profiles. Protein components of bacteria grown for various times in the X-and the C-media were analysed by SDS polyacrylamide-gel electrophoresis. Previous work (Wardlaw et al., 1976; Dobrogosz et al., 1979) had established a correlation between $\mathrm{X}$ to $\mathrm{C}$ modulation and the loss of certain major polypeptides of the cell envelope ("X-specific" polypeptides). The present study showed that the X-specific polypeptides of mol. wt 28000 and 30000 and at least one component of high mol. wt $(>68000)$ had undergone a marked reduction when an X-mode inoculum was incubated in C-medium for $10 \mathrm{~h}$ at $35^{\circ} \mathrm{C}$. Thus, the loss of these polypeptides occurred roughly in parallel with the loss of the pathophysiological activities.

\section{$C$ to $X$ reversion}

The reversion of $\mathrm{C}$-mode cells to $\mathrm{X}$-mode was examined to determine

TABLE IV

$H S F, H L T$ and LPF activities in cells during $X$ to $C$ and $C$ to $X$ modulation. Cells for assay were taken after incubation for $48 \mathrm{~h}$

\begin{tabular}{|c|c|c|c|c|}
\hline \multirow[t]{2}{*}{$\begin{array}{l}\text { Culture } \\
\text { inoculum }\end{array}$} & \multirow[t]{2}{*}{$\begin{array}{l}\text { Growth } \\
\text { medium }\end{array}$} & \multicolumn{2}{|c|}{$\begin{array}{l}\text { Relative potency } \\
\text { (and 95\% confi- } \\
\text { dence limits) of }\end{array}$} & \multirow{2}{*}{$\begin{array}{l}\text { LPF activity* expressed } \\
\text { as white blood cells } / \mathrm{mm}^{3} \\
\text { (and } 95 \% \text { confidence limits) }\end{array}$} \\
\hline & & HSF & HLT & \\
\hline C-mode & $\mathrm{X}$-medium & $\begin{array}{c}65 \\
(42-102)\end{array}$ & $\begin{array}{c}77 \\
(43-134)\end{array}$ & $\begin{array}{c}37325 \\
(33924-41081\end{array}$ \\
\hline C-mode & $\mathrm{C}$-medium & 1.2 & 16 & 9678 \\
\hline X-mode & C-medium & 2.5 & 22 & $\begin{array}{c}11781 \\
11441)\end{array}$ \\
\hline X-mode & $\mathrm{X}$-medium & $\begin{array}{c}(0 \cdot 9-7 \cdot 4) \\
100 \dagger \\
(63-160)\end{array}$ & $\begin{array}{c}(13-28) \\
100 \dagger \\
(56-176)\end{array}$ & $\begin{array}{c}(10027-13842) \\
45919 \\
(43463-48514)\end{array}$ \\
\hline
\end{tabular}

HLT $=$ heat-labile toxin; other abbreviations as in tables II and III.

* Saline control = 7991 (5917-10065).

$\dagger 48 \mathrm{~h} \mathrm{X}$-mode cells taken as reference standard and assigned the value 100 . 
whether modulation in a defined liquid medium was freely reversible, as reported by Lacey (1960) who used a blood-containing agar medium. $\mathrm{X}$-medium was seeded with cells that had been grown for $48 \mathrm{~h}$ in $\mathrm{C}$-medium (C-mode cells) and the cultures were incubated for $48 \mathrm{~h}$ at $35^{\circ} \mathrm{C}$. Control cultures of $\mathrm{C}$-mode cells seeded into $\mathrm{C}$-medium and $\mathrm{X}$-mode cells seeded into $\mathrm{X}$ - and C-media were tested in parallel.

Table IV shows that HSF, HLT and LPF activities were regained during growth of the initially $\mathrm{C}$-mode cells in the X-medium for $48 \mathrm{~h}$. There was no significant difference in HSF and HLT activity between these cells and normal $\mathrm{X}$-mode cells, and LPF activity had been restored almost to normal levels.

\section{Discussion}

$\mathrm{X}$-mode cells of $B$. pertussis grown in $\mathrm{C}$-medium undergo a rapid and extensive loss of pathophysiological activities; these are protective activity, histamine-sensitising activity, leukocytosis-promoting activity and heat-labile toxicity. Within $10 \mathrm{~h}$ of seeding X-mode cells into $\mathrm{C}$-medium, and before the onset of the logarithmic phase of growth, the activities of PA, HSF and LPF had declined to only $2-20 \%$ of their initial levels. Moreover, the X-mode specific envelope polypeptides of mol. wt 28000 and 30000 had largely disappeared by $10 \mathrm{~h}$. The rapidity of these losses was greater than could be explained by a simple growth-dilution effect and was not due to release of activity into the culture supernate. We conclude from these results that selective destruction of these envelope components had occurred.

Lacey (1960) reported that the transition from X-mode to C-mode occurred between 21 and $36 \mathrm{~h}$ during growth on a blood-containing agar medium with a high concentration of $\mathrm{MgSO}_{4}$ and required 7-12 cell divisions. The more rapid modulation observed in the present study could be due to the different medium or to the larger inoculum. Moreover, Lacey regarded changes in agglutinogens and mouse intranasal virulence as primary criteria of modulation whereas we used the four pathophysiological activities and the envelope polypeptide pattern.

There was some evidence that the activities were lost at different rates during modulation. PA appeared to be lost faster than HSF and LPF whereas HLT was lost less rapidly than HSF. An X-mode inoculum incubated in $\mathrm{C}$-medium for $10 \mathrm{~h}$ had only $2 \%$ of its original PA and about $12 \%$ of its original HSF activity. This was a consistent result and confirms a previous report (Wardlaw et al., 1976). The results of Pusztai and Joó (1967) showed the same more rapid loss of PA than HSF with three $B$. pertussis strains modulated by growth in a medium with a high concentration of nicotinic acid. This medium, however, did not cause extensive loss of HLT. Stainer (1979) also noted that PA and HSF do not necessarily occur in a fixed ratio of activities in cells grown on different media.

The most recent fractionation studies on $B$. pertussis cells or supernates suggest that HSF and LPF are different activities of the same cellular component (Morse, 1977; Yajima et al., 1978; Irons and MacLennan, 1979). 
In the present work, cells grown for $10 \mathrm{~h}$ in $\mathrm{C}$-medium contained $20 \%$ of the LPF activity but only $11 \%$ of the HSF activity of their X-mode counterparts. This indicates that although HSF and LPF may reflect different activities of a single component, the quantitative expression of activity in the living animal may be influenced by other substances. This conclusion is supported by the finding that endotoxin alters the slope of the dose-response line of purified LPF (Kurokawa et al., 1978). Moreover, HSF activity in B. pertussis cells is enhanced by sonication (unpublished observations) or by treatment with detergent (Munoz and Cole, 1979) which shows that the dispersion of cell components may affect the quantitative expression of a pathophysiological activity.

The mechanism of antigenic modulation in B. pertussis is not known, but a possible role for adenylate cyclase as a regulator of gene expression is suggested by the low activity of this enzyme in C-mode cells (Parton and Durham, 1978). However, the studies reported here indicate that not only is there a cessation of synthesis of certain virulence and other factors of $B$. pertussis in C-medium, but there is active destruction of these factors in the cells of the X-mode inoculum.

Whether this is due to selective enzymatic degradation or to some other mechanism remains to be investigated.

\section{REFERENCES}

Dobrogosz, W. J., Ezzell, J. W., Kloos, W. E. and Manclark, C. R. 1979. Physiology of Bordetella pertussis. In Proceedings of the 3rd International symposium on pertussis 1978, edited by C. R. Manclark and J. C. Hill, US DHEW publication no, (NIH) 79-1830, Washington DC. p. 86.

FINNEY, D. J. 1964. Statistical method in biological assay, 2nd ed., Grippen, London.

IRONS, L. I. AND MACLENNAN, A. P. 1979. Isolation of the lymphocytosis promoting factor-haemagglutinin of Bordetella pertussis by affinity chromatography. Biochim. biophys. Acta., 580, 175.

KurokaWa, M., Ishida, S., Asakawa, S. AND IwaSA, S. 1978. Attempts at analysis of toxicity of pertussis vaccine. III. Effects of endotoxin on leukocytosis in mice due to lymphocytosis-promoting factor and reference preparations for determination of lymphocytosispromoting factor. Jap. J. med. Sci. Biol. 31, 91.

LACEY, B. W. 1960. Antigenic modulation of Bordetella pertussis. J. Hyg., Camb., 58, 57.

LeSLIE, P. H. AND GARDNER, A. D. 1931. The phases of Haemophilus pertussis. J. Hyg., Camb., $31,423$.

Livey, I., Parton, R. and Wardlaw, A. C. 1978. Loss of heat-labile toxin from Bordetella pertussis grown in modified Hornibrook medium. F.E.M.S. Microbiol. Lett., 3, 203.

MORSE, S. I. 1977. Lymphocytosis-promoting factor of Bordetella pertussis: isolation, characterization and biological activity. J. infect. Dis., 136, supplement, S234.

Munoz, J. 1971. Protein toxins from Bordetella pertussis. In Microbial toxins, edited by S. Kadis, T. C. Montie and S. J. Ajl, Academic Press, London, vol. IIA, p. 271.

MunOZ, J. J. AND COLE, R. L. 1979. Extraction of pertussigen from Bordetella pertussis with aid of triton X-100. I.R.C.S. Med. Sci., 7, 218.

Parton, R. AND DuRham, J. P. 1978. Loss of adenylate cyclase activity in variants of Bordetella pertussis. F.E.M.S. Microbiol. Lett., 4, 287.

Parton, R. ANd Wardlaw, A. C. 1975. Cell envelope proteins of Bordetella pertussis. J. med. Microbiol., 8, 47.

PUSZTAI, Z. AND Joó, I. 1967. Influence of nicotinic acid on the antigenic structure of Bordetella pertussis. Annls Immunol. hung., 10, 63. 
Stainer, D. W. 1979. In Proceeding of the 3rd International symposium on pertussis 1978, edited by C. R. Manclark and J. C. Hill, US DHEW publication no. (NIH) 79-1830, Washington DC. p. 137.

Wardlaw, A. C., Parton, R. AND Hooker, M. J. 1976. Loss of protective antigen histamine-sensitising factor and envelope polypeptides in cultural variants of Bordetella pertussis. J. med. Microbiol., 9, 89.

Yajima, M., Hosoda, K., Kanbayashi, Y., Nakamura, T., Takahashi, I. and Ui, M. 1978. Biological properties of islets-activating protein (IAP) purified from the culture medium of Bordetella pertussis. J. Biochem., 83, 305. 